\title{
Uraren azidotasunari buruzko ikerketa Bizkaiko hiru estuariotan: Urdaibai, Plentzia eta Nerbioi-Ibaizabal
}

\author{
(Study of acidification in three estuaries of Biscay: \\ Urdaibai, Plentzia and Nerbioi-Ibaizabal)
}

\author{
Leire Kortazar*1,2, Luis Ángel Fernández, ${ }^{1,2}$ \\ ${ }^{1}$ Kimika Analitikoa Saila, Zientzia eta Teknologia Fakultatea (UPV/EHU) \\ ${ }^{2}$ Plentziako Itsas-Estazioa (PiE-UPV/EHU)
}

\begin{abstract}
LABURPENA: Lurraren \% 70 estaltzen dutelarik, ozeanoek zeresan handia dute planetaren prozesu gehienetan. Azken 200 urteetan $\mathrm{CO}_{2}$-aren emisioak gorakada handia izan du gizakien jarduera dela eta. Horren ondorioz, atmosferako $\mathrm{CO}_{2}$-aren kontzentrazioa $280 \mathrm{ppm}$-tik $415 \mathrm{ppm}$ ingurura igo da garai aurreindustrialetik gaur egunera bitartean. Zenbait ikerketaren arabera, 2100. urterako kontzentrazioak 936 ppm-ko mailara irits daitezke, isuriek orain arte bezala jarraituz gero. $\mathrm{CO}_{2}$-aren hazkundeak bi efektu nagusi ditu: alde batetik, tenperatura globalaren igoera, hau da, berotegi efektuaren areagotzea; eta bestetik, ozeanoen azidotasuna. Ozeanoek $\mathrm{CO}_{2}$-a absorbatzen dute, eta, ondorioz, atmosferan dagoen kontzentrazioa murrizten da, baina horrek uraren $\mathrm{pH}$-a jaitsiarazten du. Itsasoko uraz gain, bereziak diren hainbat gune ikertzearen beharra ere agertu da, hala nola estuarioak. $\mathrm{CO}_{2}$-aren hazkundeak ur-sistema horietan izan dituen efektuak ez dira gehiegi aztertu, eta oso garrantzitsuak dira, zeren eta animalia- eta landare-espezie askoren bizileku baitira. Azidotasuna aztertzeko, lau parametro erabiltzen dira: alkalinitate totala, disolbatutako karbono ezorganikoa, $\mathrm{pH}$-a eta iheskortasuna. Haien arteko erlazio termodinamikoa dela eta, esperimentalki soilik bi neurtu behar dira beste biak kalkulatu ahal izateko. Lan honetan, alkalinitate totala eta disolbatutako karbono ezorganikoa neurtu dira. Lau parametro horien azterketa egin da Bizkaiko hiru estuariotan: Urdaibai, Plentzia eta Nerbioi-Ibaizabal. Laginketak hiru urtez egin ziren, urtaro guztietan, estuarioen arteko berdintasunak eta ezberdintasunak ikusi nahian, bai eta denborarekiko erlazioak aztertu nahian ere.
\end{abstract}

HITZ GAKOAK: azidotasuna, $\mathrm{CO}_{2}$-aren sistema, estuarioak.

ABSTRACT: Oceans cover around a 70\% of the planet surface and play a key role in the Earth's major processes. In the last 200 years, $\mathrm{CO}_{2}$ emissions have increased due to human activities. Atmospheric $\mathrm{CO}_{2}$ concentration has increased from the preindustrial level of 280 ppm to around 415 ppm nowadays, and according to some studies, it may reach values of 936 ppm by 2100 , if emissions continue unabated. The increase of $\mathrm{CO}_{2}$ concentration has two main effects: the rise of the global temperature, known as the intensification of the greenhouse effect; and ocean acidification. Oceans absorb CO $\mathrm{O}_{2}$ excess, lowering its concentration in the atmosphere but decreasing the pH of the water. Besides seawater, the necessity of researching other interesting water systems, such as estuaries, has been signaled. The effects of $\mathrm{CO}_{2}$ increase have not been widely studied in these systems, which are considered very important since they are the habitat for a lot of species of animals and plants. There are four measurable parameters to study the $\mathrm{CO}_{2}$ system: total alkalinity, dissolved inorganic carbon, pH and fugacity. Due to their thermodynamic relationship, it is only necessary to empirically measure two of them to calculate the other two. In this work, the total alkalinity and the dissolved inorganic carbon were measured. These four parameters were studied in three estuaries of Biscay: Urdaibai, Plentzia and Nerbioi-Ibaizabal. Samples were collected for 3 years, in each season, in order to see similarities and differences between the estuaries and to study possible trends with time.

KEYWORDS: Acidification, $\mathrm{CO}_{2}$ system, Estuaries.

* Harremanetan jartzeko / Corresponding author: Leire Kortazar, Kimika Analitikoa Saila, Zientzia eta Teknologia Fakultatea (UPV/EHU), Sarriena auzoa, zg, 48940. Leioa, Euskal Herria. - leire.kortazar@ehu.eus - https://orcid.org/0000-0002-2922429X.

Nola aipatu / How to cite: Kortazar, Leire; Fernández, Luis Ángel (2020). "Uraren azidotasunari buruzko ikerketa Bizkaiko hiru estuarioetan: Urdaibai, Plentzia eta Nerbioi-lbaizabal»; Ekaia, ale berezia 2020, 125-144. (https://doi.org/10.1387/ekaia.21030).

Jasoa: 24 uztaila, 2019; Onartua: 06 azaroa, 2019

ISSN 0214-9001 - elSSN 2444-3255 / (c) 2020 UPV/EHU

(c) (i) () Obra hau Creative Commons Atribución 4.0 Internacional-en

lizentziapean dago 


\section{SARRERA}

Lurraren $\% 70$ estaltzen dutelarik, ozeanoek zeresan handia dute planetaren prozesu gehienetan. Izan ere, milaka espezie eta organismoren bizitoki izanda, bizidun ugari dituen ekosistema dira.

Azken 200 urteetan, $\mathrm{CO}_{2}$-aren emisioak ia \% 50eko igoera izan du gizakien jarduera dela eta, erregai fosilen konbustioagatik eta deforestazioagatik, batez ere [1]. Horren ondorioz, atmosferako $\mathrm{CO}_{2}$-aren kontzentrazioa bolumeneko milioiko 280 partetik (280 ppm) 415 ppm-ra igo da garai aurre-industrialetik gaur egunera (https://www.esrl.noaa.gov/ $\mathrm{gmd} / \mathrm{ccgg} /$ trends/ webgunean maiz eguneratua). Zenbait ikerketaren arabera, 2100. urterako kontzentrazioak 936 ppm-ko mailara irits daitezke isuriek kontrolik gabe jarraituz gero $[2,3] . \mathrm{CO}_{2}$-aren hazkundearen efektu garrantzitsuenetariko bat tenperatura globalaren igoera da, hau da, berotegi efektuaren areagotzea. Horretaz gain, gaur egun kezka larria bihurtu den ozeanoen azidotasuna ere arazo bilakatzen ari da. Isurtzen den $\mathrm{CO}_{2}$-aren \% 30 ozeanoek absorbatzen dute, eta ondorioz, atmosferan dagoen kontzentrazioa murriztu egiten da, baina aldi berean uraren $\mathrm{pH}$-a jaitsi da. Atmosferako $\mathrm{CO}_{2}$-a uretan absorbatzen denean, $\mathrm{CO}_{2}{ }^{*}$-a eratzen da, $\mathrm{H}_{2} \mathrm{CO}_{3}$-aren eta disolbatutako $\mathrm{CO}_{2}$-aren arteko batuketa dena: $\mathrm{CO}_{2}{ }^{*}=\left[\mathrm{CO}_{2}(\mathrm{aq})\right]+\left[\mathrm{H}_{2} \mathrm{CO}_{3}\right]$ [4]. Itsasoaren $\mathrm{pH}$-a dela eta, $\mathrm{CO}_{2}{ }^{*}$-a disoziatzen da eta $\mathrm{HCO}_{3}^{-}$eta $\mathrm{H}^{+}$ioiak eratzen dira. Era berean, azken horiek $\mathrm{CO}_{3}{ }^{2-}$-arekin erreakzionatzen dute, eta ondorioz, $\mathrm{HCO}_{3}{ }^{-}$ioiak askatzen dira. Horri itsasoaren tanpoi-ahalmena deritzo, eta $\mathrm{pH}$-aren aldaketak neutralizatzeko ahalmena da. Atmosferan gehiegizko $\mathrm{CO}_{2}$ egoteak $\mathrm{pH}$-aren neutralizazio-gaitasuna oztopatzen du. Izan ere, $\mathrm{CO}_{2}$-aren kontzentrazio handiak uretan disolbatzean, oreka protoiaren eraketara desplazatzen da, eta uraren azidotasuna handitu egiten da. Gainera, $\left[\mathrm{H}^{+}\right]-$ren hazkuntzak karbonato ioien murrizpena bultzatzen du:

$$
\left[\mathrm{H}^{+}\right]+\left[\mathrm{CO}_{3}^{2-}\right] \leftrightarrows\left[\mathrm{HCO}_{3}^{-}\right]
$$

Azken hori ozeanoetako arazo larria bihurtu da, $\mathrm{CO}_{3}{ }^{2-}$ ioiaren kontzentrazioaren murrizketak karbonatodun mineralen sorkuntza eragotzi duelako, eta itsas biota kaltetu, moluskuen oskolak $\mathrm{CaCO}_{3}$ - $\mathrm{z}$ osatuta baitaude (aragonitoa eta kaltzita batez ere) [5-7]:

$$
\mathrm{CaCO}_{3} \leftrightarrows\left[\mathrm{Ca}^{2+}\right]+\left[\mathrm{CO}_{3}{ }^{2-}\right]
$$

Azidotasuna aztertzeko eta karbonoaren sistema ezagutzeko, lau parametro erabiltzen dira, hala nola, alkalinitate totala (TA), disolbatutako karbono ezorganikoa (DIC), $\mathrm{pH}$-a eta $\mathrm{CO}_{2}$-aren presio partziala $\left(\mathrm{pCO}_{2}\right)$ edo iheskortasuna $\left(\mathrm{fCO}_{2}\right)$. Haien arteko erlazio termodinamikoa dela, tenperatura, indar ionikoa, presioa eta bestelako espezie azido-baseen kontzentra- 
zioak ezagunak badira, bi parametro esperimentalki determinatuz nahikoa da beste biak kalkulatzeko $[8,9]$.

\section{Alkalinitate totala (TA)}

Andrew Dickson-en definizioa da gaur egun erabiltzen dena [10]. Haren definizioaren arabera, itsasoko uraren alkalinitate totala hidrogeno ioi molen kantitatea da, zeina gehiegizko protoi hartzaileen kopuruaren (azido ahuletatik sortutako baseak zeinen disoziazio konstantea $\mathrm{K}_{\mathrm{a}}<10^{-4.5}, 25^{\circ} \mathrm{C}$ tan eta zero indar ionikoan) eta protoi emaileen kopuruaren $\left(\mathrm{K}_{\mathrm{a}}>10^{-4.5} \mathrm{du}-\right.$ ten azidoak) ezberdintasunaren baliokidea baita laginaren kilogramo batean.

Honela deskribatzen da:

$\mathrm{TA}=\left[\mathrm{HCO}_{3}{ }^{-}\right]+2\left[\mathrm{CO}_{3}{ }^{2-}\right]+\left[\mathrm{B}(\mathrm{OH})_{4}^{-}\right]+\left[\mathrm{OH}^{-}\right]+\left[\mathrm{HPO}_{4}{ }^{2-}\right]+2\left[\mathrm{PO}_{4}{ }^{3-}\right]+$

$\left[\mathrm{SiO}(\mathrm{OH})_{3}{ }^{-}\right]+\left[\mathrm{HS}^{-}\right]+2\left[\mathrm{~S}^{2-}\right]+\left[\mathrm{NH}_{3}\right]-\left[\mathrm{H}^{+}\right]-\left[\mathrm{HSO}_{4}^{-}\right]-[\mathrm{HF}]-\left[\mathrm{H}_{3} \mathrm{PO}_{4}\right]$

Gaur egun, TA-ren determinazioa balorazio potentziometriko batean oinarritzen da. Teknika horretan, lagina azido baten bidez potentziometrikoki baloratzen da, protoiarekiko sentikorra den elektrodo batekin. Datu potentziometrikoetatik TA kalkulatzeko, O. Johansson eta M. Wedborg-ek [11] eta Dickson-ek [10] proposatutako ekuazioak dira erabilienak (ikusi 2.4 atala).

\section{Disolbatutako karbono ez-organikoa (DIC)} hau da:

DIC-a $\mathrm{CO}_{2}$-aren sistemako espezieen kontzentrazioen batuketa da [8],

$$
\mathrm{DIC}=\left[\mathrm{CO}_{2}{ }^{*}\right]+\left[\mathrm{HCO}_{3}{ }^{-}\right]+\left[\mathrm{CO}_{3}{ }^{2-}\right]
$$

DIC-a neurtzeko metodo arruntenak uraren azidotasunean oinarritzen dira. Modu honetan, laginean dauden karbono-espezie guztiak $\mathrm{CO}_{2}(\mathrm{~g})$ izatera pasatzen dira, eta azken honen detekzioa bi modutan egiten da: infragorri (IR) detektagailu baten bidez edo coulombimetrikoki baloratuz eta fotometrikoki detekzioa eginez [8].

\section{pH}

$\mathrm{pH}$-ak hidrogeno ioiaren kontzentrazioa adierazten du. Ozeanografian hiru $\mathrm{pH}$ eskala erabiltzen dira: hidrogeno ioi librearena, hidrogeno ioi totalarena eta itsasoko urarena, hain zuzen. Kasu guztietan, $\mathrm{pH}-\mathrm{a}$ neurtzeko teknika ezagunenak potentziometrikoa eta espektofotometrikoa dira $[4,12]$. 
Hidrogeno ioi librearen eskala definizio originalaren antzekoa da, eta hidrogeno ioi libreen kontzentrazioa bakarrik hartzen du kontuan, hau da, molekularik eratzen ari ez den hidrogeno ioien kontzentrazioa. Eskala hori honela definitua dago $[13,14]$ :

$$
\mathrm{pH}_{\mathrm{F}}=-\log \left(\frac{\mathrm{m}_{\mathrm{H}^{+}}}{\mathrm{m}^{0}}\right)
$$

non $\mathrm{m}_{\mathrm{H}}{ }^{+}$hidrogeno ioi libreen kontzentrazioa baita, eta $\mathrm{m}^{0}$ molalitate estandarra baita, $1 \mathrm{~mol} / \mathrm{kg}$ balioa duena.

Hidrogeno ioi totalen eskalak, $\mathrm{HSO}_{4}^{-}$ioiaren presentzia kontuan hartzen du, eta honela definitzen da $[15,16]$ :

$$
\mathrm{pH}_{\mathrm{T}}=-\log \left(\frac{\mathrm{m}_{\mathrm{H}_{\mathrm{T}}}}{\mathrm{m}^{0}}\right)
$$

non

$$
\mathrm{m}_{\mathrm{H}_{\mathrm{T}}}=\mathrm{m}_{\mathrm{H}^{+}}+\mathrm{m}_{\mathrm{HSO}_{4}^{-}}=\mathrm{m}_{\mathrm{H}^{+}}\left[1+\frac{\mathrm{m}_{\mathrm{SO}_{4}^{2-}}}{\mathrm{k}_{\mathrm{HSO}_{4}^{-}}}\right]
$$

non $\mathrm{m}_{\mathrm{so} 4}{ }^{-2}$ sulfato ioiaren kontzentrazio librea baita, eta $\mathrm{k}_{\mathrm{HSO} 4}{ }^{-}$bisulfato ioiaren disoziazio konstante estekiometrikoa $[17,18]$.

Itsasoko uraren eskalak sulfato eta fluoruro ioien presentzia kontuan hartzen du, eta honela definitzen da $\mathrm{pH}-\mathrm{a}[16,19,20]$ :

$$
\mathrm{pH}_{\mathrm{SWS}}=-\log \left(\frac{\mathrm{m}_{\mathrm{H}_{\mathrm{sw}}}}{\mathrm{m}^{0}}\right)
$$

non

$$
\mathrm{m}_{\mathrm{H}_{\mathrm{sws}}}=\mathrm{m}_{\mathrm{H}^{+}}+\mathrm{m}_{\mathrm{HSO}_{4}^{-}}+\mathrm{m}_{\mathrm{HF}}=\mathrm{m}_{\mathrm{H}^{+}}\left[1+\frac{\mathrm{m}_{\mathrm{SO}_{4}^{2-}}}{\mathrm{k}_{\mathrm{HSO}_{4}^{-}}}+\frac{\mathrm{m}_{\mathrm{F}^{-}}}{\mathrm{k}_{\mathrm{HF}}}\right]
$$

non $\mathrm{mF}^{-}$fluoruroaren kontzentrazio librea baita, eta $\mathrm{k}_{\mathrm{HF}}$ hidrogeno fluoruroaren disoziazio konstante estekiometrikoa [20].

Ondoriozta daitekeenez, $\mathrm{pH}$-aren determinazioa egiten denean, beharrezkoa da jakitea zer $\mathrm{pH}$-eskalatan eta zer kontzentrazio-eskalatan egin diren neurketak, ikerketa ezberdinekiko konparazioak errazteko. 


\section{$\mathrm{pCO}_{2}$ eta $\mathrm{fCO}_{2}$}

Itsasoko ur lagin batekin orekan dagoen $\mathrm{pCO}_{2}$-a, lagin horren $\mathrm{CO}_{2}$ gasarekiko asetze-mailaren neurketa da. Termodinamikan, iheskortasuna erabiltzea aproposagoa da. Izan ere, gas erreal baten $\mathrm{fCO}_{2}$-ak gas idealetarako erabiltzen den presio partzial mekanikoa ordezkatzen du. Honela determinatzen da: itsasoko uraren kantitate ezagun bat sistema itxi batean jartzen da $\mathrm{CO}_{2}$ kontzentrazio jakin bat duen eta ezaguna den aire bolumen txiki batekin. Behin ura eta airea orekan daudenean, airearen $\mathrm{CO}_{2}$-aren kontzentrazioa neurtzen da infragorri detektagailu baten bidez [4].

Azidotasunak izan dezakeen ondorio txar guztiengatik, itsasoko uraren azidotasuna aztertzeko beharra ikusi da azken urteetan. Hala ere, itsasoko uraz gain, bereziak diren hainbat gune ikertzearen beharra ere agertu da, hala nola estuarioak. Estuarioa itsasoko ura eta ur geza elkartzen diren ibaiaren ahoa da, eta, ondorioz, marearen eragin handia izaten dute [21]. Ozeanoek berezko alkalinitatea mantentzeko joera dute, ur bolumen handiak direlako, eta horregatik esaten da tanpoi moduan jokatzen dutela. Aldiz, estuarioak sentikorragoak dira azidotasunaren fenomenoaren aurrean, tanpoi-gaitasun txikiagoa izan ohi dutelako [22], normalean karbonato ioien kontzentrazioa txikiagoa delako. Esan bezala, estuarioak gune bereziak dira bi motatako urak elkartzen direlako haietan, eta, hori dela eta, estuarioen azidotasunaren ikerketa konplexuagoa da itsasoko azidotasunarena baino. Hala ere, oso garrantzitsua da haiek aztertzea, animalia- eta landareespezie askoren bizileku direlako [23].

Hala, lan honetan Bizkaiko hiru estuario aztertu dira: Nerbioi-Ibaizabal, Butroi eta Urdaibai. Estuario horiek hurbil daude elkarren artean $(<50 \mathrm{~km})$, eta antzeko geomorfologia partekatzen dute, hala nola, sakonera txikiko urak dituzte $(<25 \mathrm{~m})$ eta laburrak dira $(<15 \mathrm{~km})$. Estuario horiek aukeratu ziren haien kutsadura-maila oso ezberdina izango zelakoan. Hau da, Urdaibai biosferako erreserba izendatu zuen UNESCO-k 1984an [24, 25]. Bestalde, Nerbioi-Ibaizabal, Bilbao hiritik pasatzen da, eta historikoki oso estuario kutsatua izan da industria-garaitik aurrera, kontrolik gabeko kutsatzaile ez-organikoen eta organikoen isurketak izan zirelako [26]. Bukatzeko, Plentziako estuarioa kutsadura baxuko estuariotzat hartzen da [27]. Ikerketa lan batzuetan, kontrol modura hartu da, eta haren kutsadura baxua egiaztatu da [28].

Beraz, lan honen helburua hiru estuario oso ezberdinetan azidotasunarekin erlazionatutako parametroak aztertzea da, estuarioen arteko antzekotasunak eta ezberdintasunak ezagutzeko. TA, DIC, pH eta iheskortasuna aztertu dira urtaro guztietan eta hiru urtez, joerak aztertu nahian. 


\section{ATAL ESPERIMENTALA}

\subsection{Ikertutako tokiak eta laginketa}

Aipatu den bezala, lan honetan Bizkaiko hiru estuario aztertu dira:

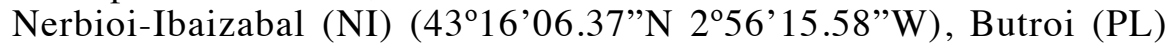
$\left(43^{\circ} 24^{\prime} 18.35\right.$ "N 2 $2^{\circ} 56^{\prime} 47.94$ 'W) eta Urdaibai (UR) $\left(43^{\circ} 23^{\prime} 34.86^{\prime \prime} \mathrm{N}\right.$ $2^{\circ} 41$ '12.84"W) (ikusi 1. irudia).

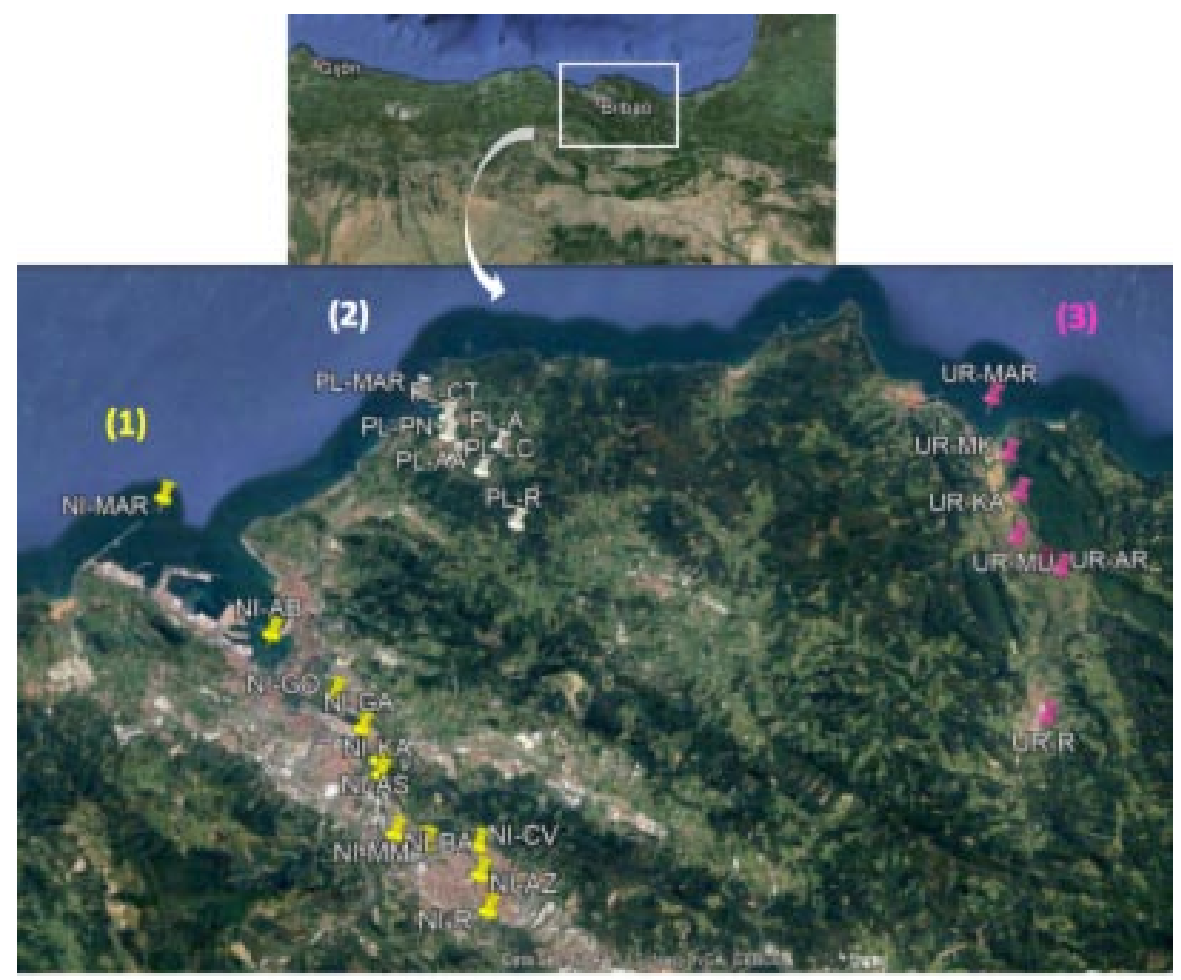

1. irudia. Laginketa puntuak: (1) Nerbioi-Ibaizabal estuarioan; hona laburdurak: MAR: itsasoa; AB: El Abra; GO: Gobelas; GA: Galindo; AS: Asua; KA: Kadagua; DK; Deustuko kanala; BA: Basurto; MM: Itsas-museoa; CV: Campo Volantin; AZ: Alde zaharra eta R: Ibaia. (2) Plentziako estuarioan; hona laburdurak: MAR: itsasoa; CT: Tenis-kluba; PN: Zubi berria; LC: La Carolina; AA: Abanikoa baino lehen; A: Abanikoa eta R: Ibaia. (3) Urdaibai estuarioan; hona laburdurak: MAR: itsasoa; MK: Mundakako kanpina; KA: Kanala; MU: Murueta; I: Elkargunea; AR: Arteaga eta R: Ibaia.

Hiru urtez batu ziren laginak (2014-2017), urtaro guztietan. Bi lagin batu ziren estuarioko laginketa-puntu bakoitzean: bata gainazalean eta 
bestea sakonera maximoan. Ibaietan, ordea, lagin bakarra hartu zen. Gainazalekoak Van Dorn botila erabiliz (KC Denmark A/S, Silkeborg, Danimarka) batu ziren eta sakonera maximokoak Niskin botila erabiliz (KC Denmark A/S, Silkeborg, Danimarka). Azken horrekin batera, EXO 2 zunda multiparametrikoa (YSI Inc., OH, USA) urperatu zen zenbait parametro fisiko-kimiko neurtzeko: tenperatura, eroankortasuna, gazitasuna, disolbatutako oxigenoa, disolbatutako materia organiko fluoreszentea, $\mathrm{pH}$-a eta oxidazio-erredukzio potentziala. TA eta DIC neurtzeko laginak $250 \mathrm{~mL}$-ko borosilikatozko botiletan batu ziren. Haiei bolumen totalaren $\%$ 1eko buru-gunea utzi zitzaien uraren espantsioa ahalbidetzeko, eta $\mathrm{HgCl}_{2}$ disoluzio ase $(60 \mathrm{~g} / \mathrm{L})$ baten $100 \mu \mathrm{L}$ gehitu zitzaizkion aktibitate biologikoa saihesteko. Fosfatoa eta silikatoa neurtzeko, laginak polipropilenozko $500 \mathrm{~mL}$-ko botiletan batu ziren, eta $4{ }^{\circ} \mathrm{C}$-tan mantendu ziren, analisia egin arte.

\subsection{Erreaktiboak eta disoluzioak}

Erreaktibo guztiak Merck (Merck kGaA, Darmstadt, Germany) etxe komertzialekoak dira, kontrakoa adierazi ezean.

Disoluzio guztiak ur ultrapurua erabiliz prestatu ziren, Millipore purifikazio-sistematik lortua (Millipore Co., MA, USA).

Disolbatutako karbono ezorganikoaren determinazioari dagokionez, laginen azidotasuna gauzatzeko $\% 10 \mathrm{v} / \mathrm{v}-\mathrm{ko}_{3} \mathrm{HO}_{4}$-ren $250 \mathrm{~mL}$-ko disoluzioa erabili zen. Zelda coulombimetrikoan jartzen diren katodo eta anodo disoluzioak UIC-tik (UIC Inc., Rockdale, IL, AEB) eskuratu ziren. Katodo disoluzioa nahaste bat da ura, etanolamina, tetraetil-amonio bromuroa eta timolftaleina dimetil sulfoxidoan (DMSO) disolbatua, eta anodoa, berriz, uretan eta DMSO-tan prestatutako KI disoluzio asea da. $\mathrm{CO}_{2}$-a mugitzeko erabili zen gas garraiatzaileari dagokionez, \% 99,999 purutasuna zuen $\mathrm{N}_{2}$ (Messer Group GmbH, Bad Soden am Taunus, Alemania) gasa zen, zeina $\mathrm{CO}_{2}$ tranpa (SUPELCO, Sigma Aldrich, MO, AEB) batetik pasarazi baitzen ekipora sartu aurretik.

Lagina zelda coulombimetrikora sartu aurretik, prestatutako ur-tranpa batetik igaro zen, magnesio perklorato anhidrido pikorkatua (Alfa Aesar, Thermo Fisher (Kandel) GmbH, Karlsruhe, Alemania) zuen ur-tranpa batetik.

Alkalinitateari dagokionez, baloratzaile moduan $0,1 \mathrm{~mol} / \mathrm{L} \mathrm{HCl}$ (Tracepur) (Merck KGaA, Darmstadt, Alemania) erabili zen, 0,6 mol/L NaCl-tan (Panreac Química SLU, Bartzelona, Espainia) prestatu zena itsasoko uraren indar ioniko bera izateko.

Lan egiteko modu hau itsaso zabaleko uretan gomendatutakoa da. Estuarioko uren kasuan, lagin guztietarako baloratzaile ezberdina erabiltzea 
ekarriko luke, eragozpena dena, baloratzaileak estandarizatua egon behar duelako. Beraz, 0,7 mol/L indar ionikoko baloratzaile bat erabiltzea erabaki zen, eta lagin guztietarako indar ionikoaren aldaketa ondoren zuzendu behar da. 10L-ko 0,7 mol/L NaCl (VWR International Eurolab S.L., Bartzelona, Espainia) garbiketa-disoluzio bat prestatu zen balorazio-zelda garbitzeko laginen neurketen tartean.

\subsection{Prozedura}

TA eta DIC determinatzeko, VINDTA 3C (Marianda Lab., Kiel, Alemania) ekipoa erabili zen. Horrek bereiztutako bi atal ditu parametro biak aldi berean neurtzeko. TA-aren determinazioa balorazio potentziometriko baten bidez burutzen da, $\mathrm{HCl}$ erabiliz $\mathrm{pH}=4$ inguru izan arte. Erreferentziazko elektrodoa $\mathrm{Ag}(\mathrm{s}) / \mathrm{AgCl}$ (s)-zkoa zen (Metrohm AG, Herisau, Suitza) eta beirazko elektrodo modura, ORION-ROSS (Thermo Orion, Thermo Fisher Scientific, MA, AEB) erabili zen, haien erantzun azkarragatik. Potentzialaren neurketa potentzial diferentzia bitartez egiten da, hau da, elektrodo bien arteko potentzial diferentzia elektrodo laguntzaile baten aurka neurtzen da, titaniozko kable bat dena (Marianda, Kiel, Alemania).

Emaitzen zehaztasuna (trazabilitatea) eta doitasuna aztertzeko, Andrew Dickson laborategiak (A. Dickson, Scripps Institution of Oceanography, San Diego, AEB) hornitutako CRM-a neurtu zen.

DIC-a determinatzeko, CM5015 Coulombimetroa erabili zen, CM5011 emuladorearekin UIC Inc-k hornitua (UIC Inc. Rockdale, IL, AEB). UIC Inc-k ere, borosilikatozko zelda hornitu zuen, zilarrezko anodoa, platinozko katodoa eta irabiagailua. Zelda erabilgarri dagoenean, katodo-disoluzioak kolore urdina du. Lagina azidotzen denean, $\mathrm{CO}_{2}$-a zeldara pasatzen da, eta azido ahul bat (azido hidroxietilkarbamikoa) eratzen da kolore urdina murriztuko duena. Azido hori coulombimetrikoki baloratzen da $\mathrm{H}_{2} \mathrm{O}-$ tik sortutako $\mathrm{OH}^{-}$erabiliz hasierako transmitantzia (\% 29.5-29.6) lortu arte detekzio fotometrikoa burutzen delarik.

Parametro bien ohiko analisi-denbora 20 minutu ingurukoa da erantzun arineko beirazko elektrodoa erabiltzen bada. VINDTA 3C erabiliz, eta Kortazar et al. [29] lanean publikatutako kalkuluak egiteko metodologia erabiliz, oso doitasun onak lortzen dira. Bai DIC eta bai TA-ren kasuetan ere, \% 0.03-0.2 tarteko desbideratze estandar erlatiboak (DEE) lortu dira ziurgabetasun osoa kontuan hartuz [29].

TA-ren kalkulua egiteko, karbono ez-organikoa izan ezik, beste espezie azido base guztien kontzentrazio totalak ezagunak izan behar dute. Silikatoa eta fosfatoa fluxu injekzio bidezko analisiaren bidez determinatu ziren molibdeno urdinaren metodoak erabiliz. Fosfatoaren prozedura 
Kortazar et al. [30] lanean aurkitu daiteke. eta silikatoaren prozedura Ma et al.-k [31] argitaratutakoaren oso antzekoa zen.

\subsection{Kalkuluen prozedura}

DIC balioen zuzenketa egiteko, egunean zehar neurtutako CRM-en balio esperimentalak erabili ziren. Azken horiek balore zertifikatuarekin zatitzean faktore zuzentzailea eskuratzen da, eta hori lagin bakoitzaren DIC-aren emaitza esperimentalekin biderkatzen da.

TA kalkulatzeko, balorazio potentziometrikoan lortzen den kurbara doitzeko, karratu txikien erregresio ez-lineala deituriko prozedura erabili zen, eta kalkulatutako bolumenaren eta esperimentalki gehitutako bolumenaren arteko diferentzia minimizatu zen.

Balorazio puntu bakoitzean, honela definitzen da hidrogeno ioiaren kontzentrazioa [12]:

$$
\begin{gathered}
\mathrm{C}_{\mathrm{H}, \mathrm{i}}=\left[\mathrm{H}^{+}\right]_{\mathrm{F}}+\left[\mathrm{HSO}_{4}^{-}\right]+[\mathrm{HF}]+\left[\mathrm{H}_{3} \mathrm{PO}_{4}\right]-\left[\mathrm{HCO}_{3}^{-}\right]-2\left[\mathrm{CO}_{3}^{2-}\right]- \\
{\left[\mathrm{B}(\mathrm{OH})_{4}^{-}\right]-\left[\mathrm{OH}^{-}\right]-\left[\mathrm{HPO}_{4}^{2-}\right]-2\left[\mathrm{PO}_{4}^{3-}\right]-\left[\mathrm{SiO}(\mathrm{OH})_{3}^{-}\right]-\left[\mathrm{NH}_{3}\right]-\left[\mathrm{HS}^{-}\right]}
\end{gathered}
$$

Disoluzioan dagoen hidrogeno ioiaren hasierako kontzentrazioa TAren balio negatiboa da. Balorazio puntu bakoitzean laginaren hasierako masari $\left(\mathrm{m}_{0}\right)$ azidoaren masa $(\mathrm{m})$ gehitzen zaio kontzentrazio ezagun batean $\left(\mathrm{C}_{\mathrm{H}}{ }^{0}\left(\mathrm{~mol} / \mathrm{kg}_{\mathrm{sw}}\right)\right)$; beraz, honela defini daiteke hidrogeno ioiaren kontzentrazioa:

$$
\mathrm{C}_{\mathrm{H}, \mathrm{i}}=\frac{-\mathrm{m}_{0} \cdot \mathrm{TA}+\mathrm{m} \cdot \mathrm{C}_{\mathrm{H}}^{0}}{\mathrm{~m}_{0}+\mathrm{m}}
$$

Beraz, (8) eta (9) ekuazioak konbinatzean:

$$
\begin{gathered}
\frac{-\mathrm{m}_{0} \cdot \mathrm{TA}+\mathrm{m} \cdot \mathrm{C}_{\mathrm{H}}^{0}}{\mathrm{~m}_{0}+\mathrm{m}}=\left[\mathrm{H}^{+}\right]_{\mathrm{F}}+\left[\mathrm{HSO}_{4}^{-}\right]+[\mathrm{HF}]+\left[\mathrm{H}_{3} \mathrm{PO}_{4}\right]-\left[\mathrm{HCO}_{3}^{-}\right]-2\left[\mathrm{CO}_{3}^{2-}\right]- \\
{\left[\mathrm{B}(\mathrm{OH})_{4}^{-}\right]-\left[\mathrm{OH}^{-}\right]-\left[\mathrm{HPO}_{4}^{2-}\right]-2\left[\mathrm{PO}_{4}^{3-}\right]-\left[\mathrm{SiO}(\mathrm{OH})_{3}^{-}\right]-\left[\mathrm{NH}_{3}\right]-\left[\mathrm{HS}^{-}\right]}
\end{gathered}
$$

Ekuazioak errazteko asmoz, (10) ekuazioaren berdinketaren eskumako atalari «term» deituko zaio hemendik aurrera.

Gainerako espezieak neurtu ziren, eta erlazio estekiometrikoekin eta masa balantzekin puntu bakoitzeko kontzentrazioak kalkulatu ziren. 
$\mathrm{m}_{\text {kalk }}$ balioa eskuratzeko, honako formula hau dugu:

$$
\mathrm{m}_{\text {kalc }, \mathrm{i}}=\frac{\mathrm{m}_{0} \cdot(\text { term }+\mathrm{TA})}{\mathrm{C}_{\mathrm{H}}^{0}+\text { term }}
$$

$\mathrm{m}_{\text {kalk }}$ balioak dentsitatearekin zatitzen dira bolumena eskuratzeko, VINDTA-k bolumen gehikuntzekin lan egiten duelako. Bukatzeko, kalkulatutako bolumenaren eta esperimentalki gehitutako bolumenaren arteko diferentzia minimizatu zen, Microsolf Excel-eko Solver aukera erabiliz. Kalkuluen prozedura hori zehazki azalduta dago Kortazar et al. [29] lanean.

TA eta DIC parametroetatik $\mathrm{pH}$-a eta iheskortasuna kalkulatzeko, CO2SYS Excel makroa erabili zen, Guide to Best Practices for Ocean $\mathrm{CO}_{2}$ Measurements [12] liburuko ekuazioei jarraituz.

\section{EMAITZAK ETA EZTABAIDA}

Nahiz eta uraren azidotasunaren inguruko ikerketak egiteko denbora luzean jasotako datuak erabiltzen diren, lan honetan hiru urteko informazioa erabili da ikusteko ikertutako estuarioaok gaur egun zein egoeratan dauden. Honako parametro hauek aztertuko dira: DIC, TA, pH eta $\mathrm{fCO}_{2}$.

\section{DIC}

2., 3. eta 4. irudiek DIC-aren kontzentrazioak erakusten dituzte UR, PL eta NI estuarioetan, hurrenez hurren.

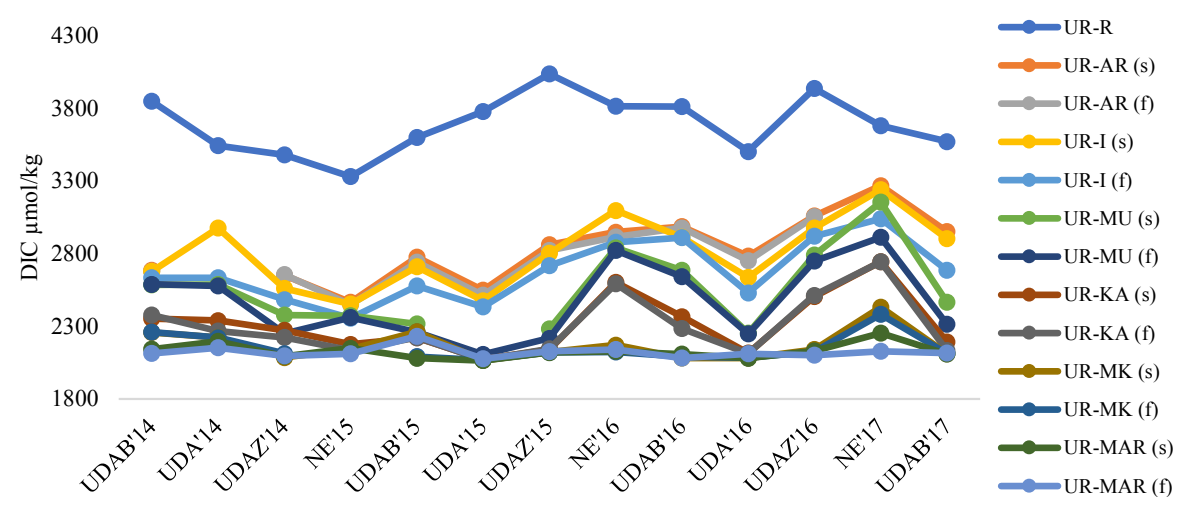

2. irudia. DIC-aren kontzentrazioak UR estuarioan laginketa kanpaina guztietan. 


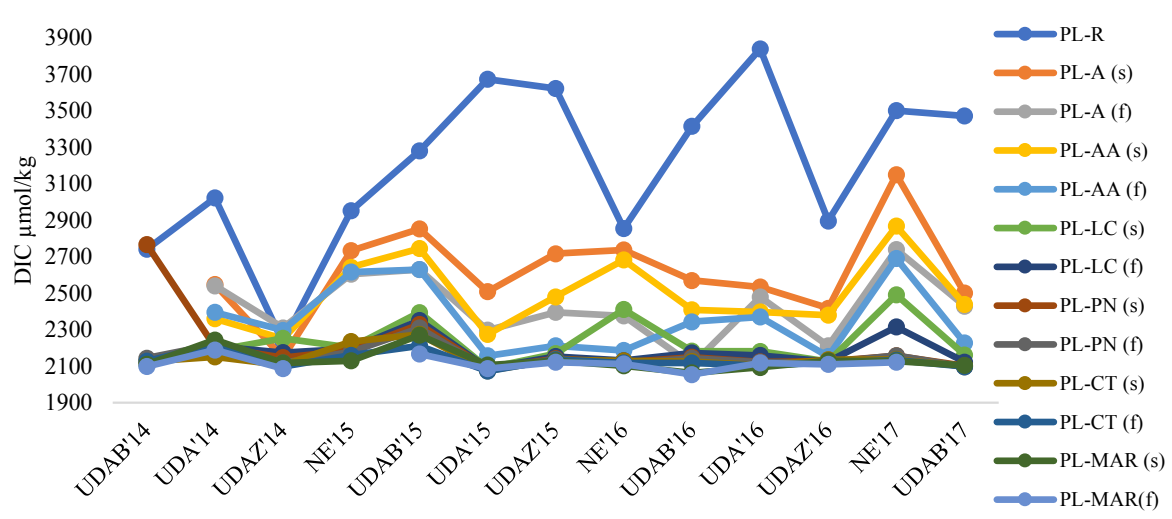

3. irudia. DIC-aren kontzentrazioak PL estuarioan laginketa kanpaina guztietan.

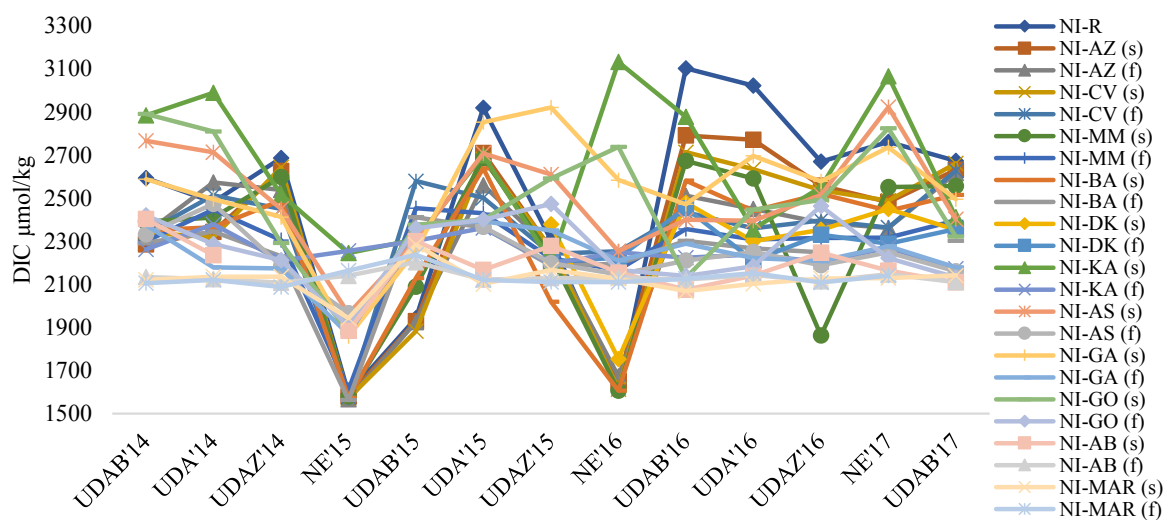

4. irudia. DIC-aren kontzentrazioak NI estuarioan laginketa kanpaina guztietan.

UR eta PL estuarioetan, ikus daiteke ibaiko lagina dela DIC balio handienak dituena, batez ere UR kasuan. Hori izan daiteke ibaien arroa mugikorrak diren karbonato-mineralez osatuta daudelako, eta hauen uretako kontzentrazioa handitzen delako. Estuarioan itsasoko uraren eraginez, DIC-a diluitu egiten da, eta, horren ondorioz, haren kontzentrazioa murriztu egiten da estuarioan zehar. Horregatik, ibaitik gertuen dauden laginketapuntuak DIC handiagoa erakusten dute. Gainazaleko laginen DIC balioak handiagoak dira sakonerakoekin konparatuz. Izan ere, uren dentsitateak direla eta, ur geza gainazaletik mugitzen da (DIC altuagoa), eta itsasoko ura sakoneratik (DIC baxuagoa). Badirudi, halaber, neguan DIC altuagoak aurkitu direla bi estuario horietan eta uda aldean baxuagoak, bereziki azken bi urteetan. Izan daiteke $\mathrm{CO}_{2}$ gasaren disolbagarritasuna tenperatura baxuetan handiagoa delako tenperatura altuetan baino [12]. Bukatzeko, UR estua- 
rioaren kasuan, gorako joera soma daiteke urteetan zehar, batez ere ibaitik gertuago dauden laginketa-puntuetan.

NI estuarioan, DIC kontzentrazioak apur bat txikiagoak dira beste biekin konparatuz, oro har, eta batez ere ibaian. NI-k dituen ibaiadarretatik hiruk erakusten dituzte kontzentrazio altuagoak: KA, AS eta GO. Badaude neguko bi laginketa oso DIC baxuak erakusten dituztenak, 2015eko eta 2016ko laginketak, hain zuzen. Horren arrazoia eguraldiarekin erlazionatuta dago. Izan ere, laginketaren egunean eta aurreko egunetan euri asko egin zuenez, estuarioak euri-ur asko zeraman, DIC baxua duena.

Hiru estuarioetan itsasoko laginek, eta baita ingurukoek ere, pareko DIC balioak erakutsi dituzte urteetan zehar, eta ez da aldaketa handirik ikusten urtaroen artean. Gainera, itsasoko balioen artean ez dago aldaketa nabarmenik hiru estuarioen artean, eta kostaldeko DIC-a ez da asko aldatzen.

\section{TA}

5., 6. eta 7. irudiek TA-aren kontzentrazioak erakusten dituzte UR, PL eta NI estuarioetan, hurrenez hurren.

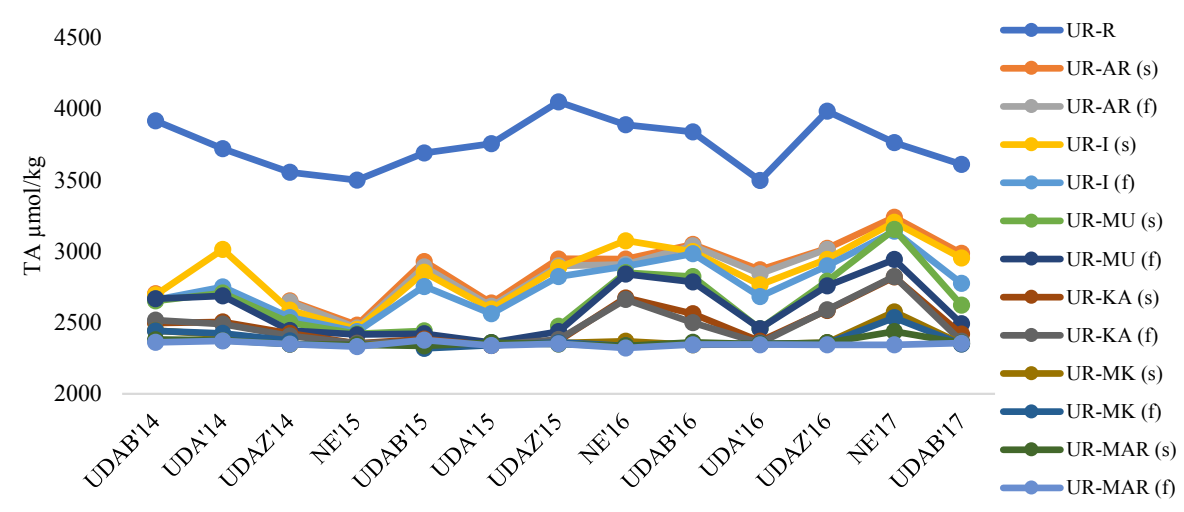

5. irudia. TA-aren kontzentrazioak UR estuarioan laginketa kanpaina guztietan.

Oro har, TA balioak DIC-arenak baino handiagoak dira, eta joerak DIC-aren berdinak dira. Izan ere, TA-ri egindako kontribuzio nagusia karbono ezorganikoari dagokio. Berriro ere, ibaiko lagina da TA handiena erakutsi duena UR eta PL kasuetan, batez ere lehenengoan, zeinetan $4.000 \mu \mathrm{mol} / \mathrm{kg}$-ra heltzen baita. NI estuarioan KA ibaiadarreko gainazaleko lagina da TA handienetakoa erakusten duena, AS eta ibaiarekin batera. 


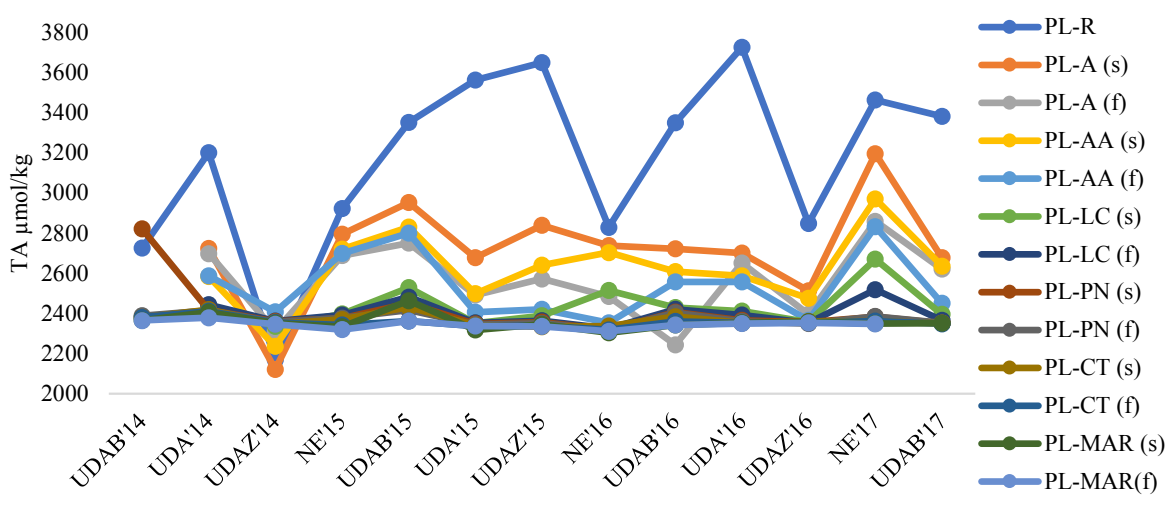

6. irudia. TA-aren kontzentrazioak PL estuarioan laginketa kanpaina guztietan.

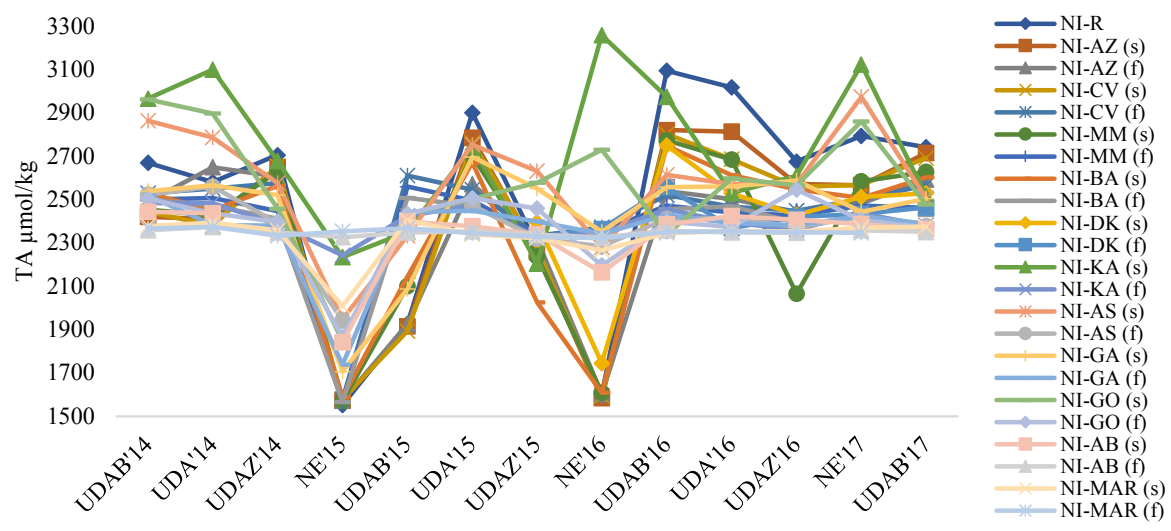

7. irudia. TA-aren kontzentrazioak NI estuarioan laginketa kanpaina guztietan.

\section{pH}

8., 9. eta 10. irudiek $\mathrm{pH}$-aren balioak erakusten dituzte UR, PL eta NI estuarioetan, hurrenez hurren. 


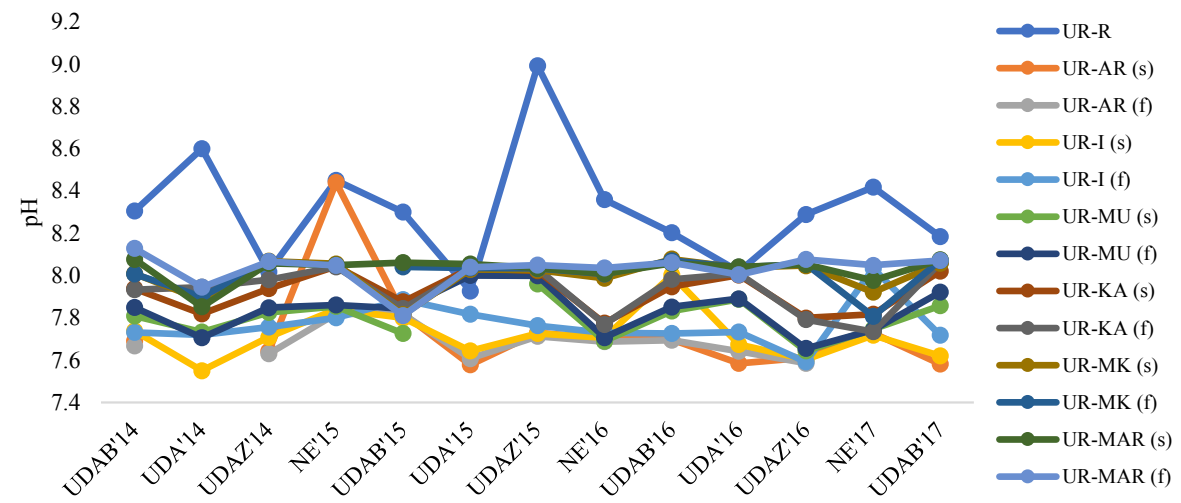

8. irudia. $\mathrm{pH}$-aren balioak UR estuarioan laginketa kanpaina guztietan.

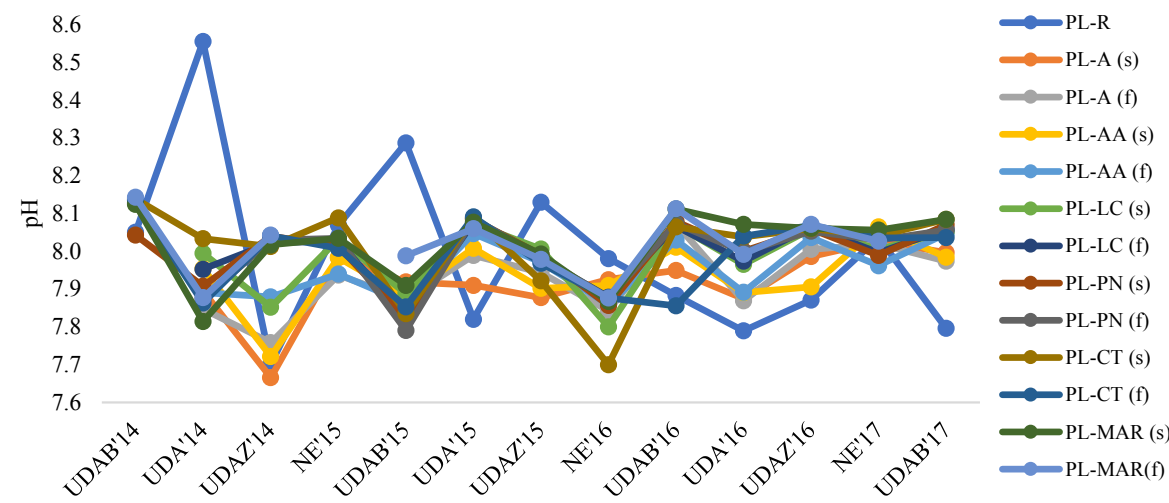

9. irudia. pH-aren balioak PL estuarioan laginketa kanpaina guztietan.

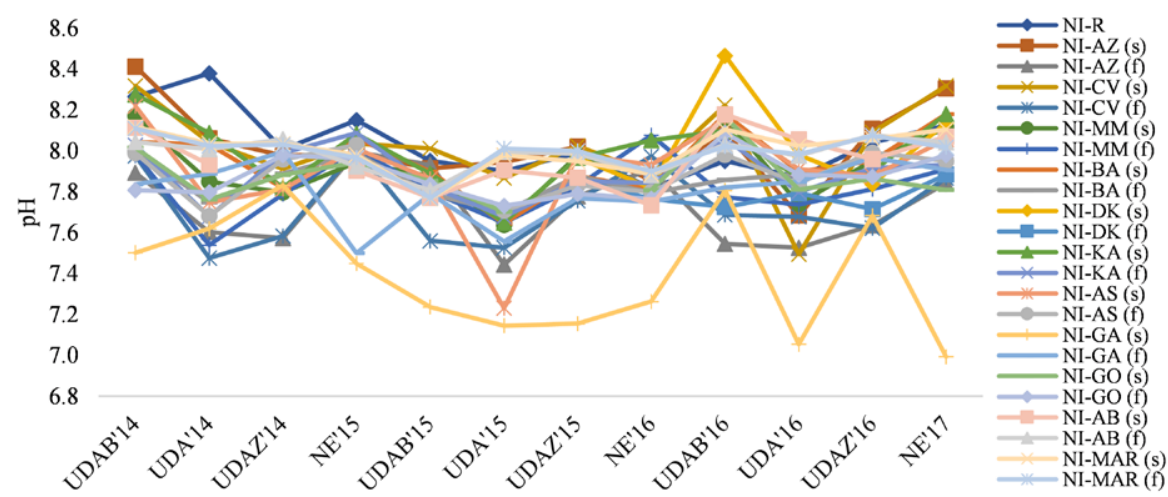

10. irudia. $\mathrm{pH}$-aren balioak NI estuarioan laginketa kanpaina guztietan. 
Urdaibai estuarioan ibaiko laginak erakutsi ditu $\mathrm{pH}$ balio altuenak, 9-ra ere heldu delarik. Aipatzekoa da ibaitik gertuen dauden puntuek $\mathrm{pH}$ balio baxuenak erakutsi dituztela, eta horiek uda inguruan izan direla baxuagoak. Plentziako estuarioan ibaitik gertu dauden puntuek $\mathrm{pH}$ baxuenak erakutsi dituzte. Baina kasu horretan ibaiak ez du joera argia erakusten, eta ezin daiteke esan urtaroari dagokion joerarik ikusten denik laginketen artean, nahiz eta aldaketa nabarmenak antzeman diren. Oro har, PL-ko pH balioak UR-ekoak baino altuagoak dira. NI estuarioan $\mathrm{pH}$-ak oso aldakorrak dira. $\mathrm{pH}$ altuagoak aurkitu dira gainazalean sakoneran baino, itsasoko eta ibaiko uren nahasketaren ondorioz, bereziki ibaitik gertuko laginketa-puntuetan. Hala ere, GA ibaiadarrak atentzio berezia eman du bere $\mathrm{pH}$ balio baxuengatik, 7-ra ere heldu delarik. Balio hau oso baxua da estuario bateko uretarako, eta bereziki baxua da gainerako laginketa puntuekin konparatuz.

\section{$\mathrm{fCO}_{2}$}

11., 12. eta 13. irudiek iheskortasunaren balioak erakusten dituzte UR, PL eta NI estuarioetan, hurrenez hurren.

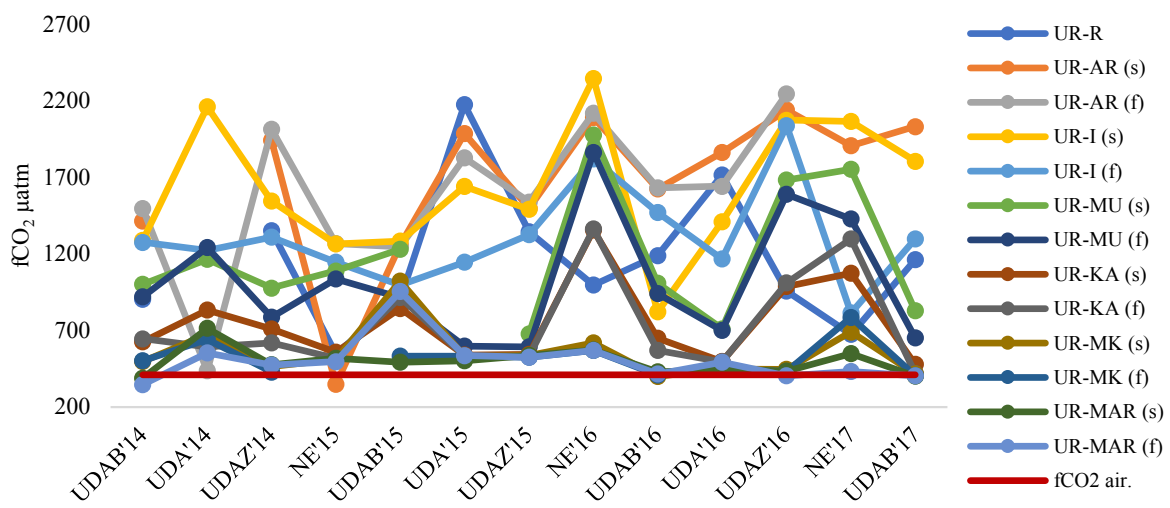

11. irudia. $\mathrm{fCO}_{2}$-aren balioak UR estuarioan laginketa kanpaina guztietan.

Lehenengo eta behin, aipatzekoa da atmosferako $\mathrm{CO}_{2}$-aren iheskortasuna 410,9 $\mu \mathrm{atm}$-koa dela (lerro gorria irudietan). Beraz, uraren $\mathrm{fCO}_{2}$-a balio hori baino txikiagoa bada, ur horrek $\mathrm{CO}_{2}$-a absorbatuko du, eta, aldiz, handiagoa bada, $\mathrm{CO}_{2}$-a askatuko du. Irudietan ikus daitekeen moduan, nabarmena da estuario hauek $\mathrm{CO}_{2}$-a askatzen dutela.

UR estuarioan ibaitik gertu dauden laginketa-puntuetan $\mathrm{CO}_{2}$-aren gainsaturazioa oso garrantzitsua da, bereziki AR eta I puntuetan. «I» puntua ibai errealaren eta kanal sintetiko baten arteko intersekzioa da. Kanal sintetiko hori, populazio handiko herrietatik igarotzen da (Gernika-Lumo, esaterako) eta inguruko hondakin-uren araztegiaren efluentearen urak ere kanal 
honetara doaz. Beraz, $\mathrm{fCO}_{2}$ balio altu horiek kanaletik datozela esan daiteke, eta bat dator $\mathrm{pH}$-balio baxuekin.

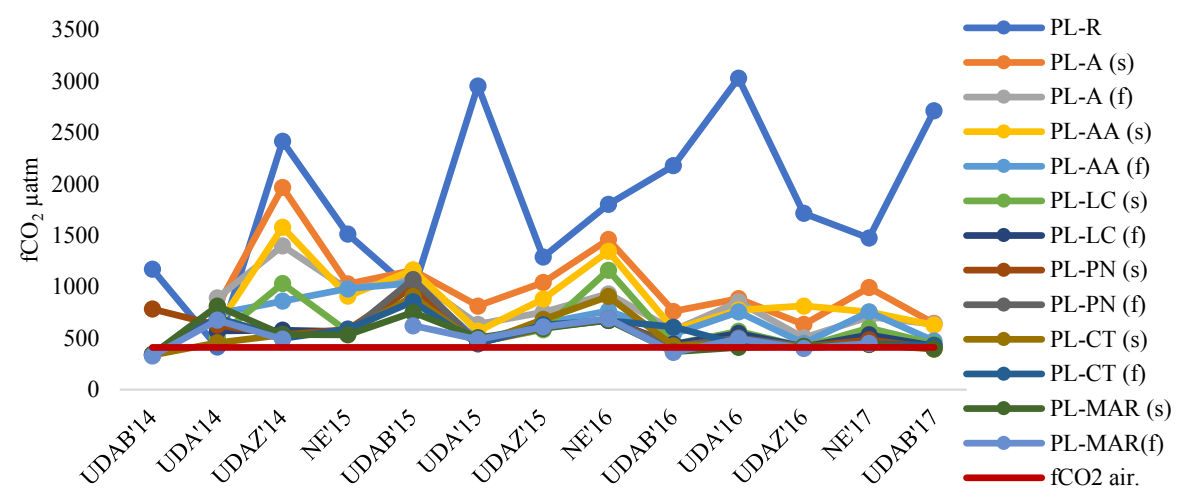

12. irudia. $\mathrm{fCO}_{2}$-aren balioak PL estuarioan laginketa kanpaina guztietan.

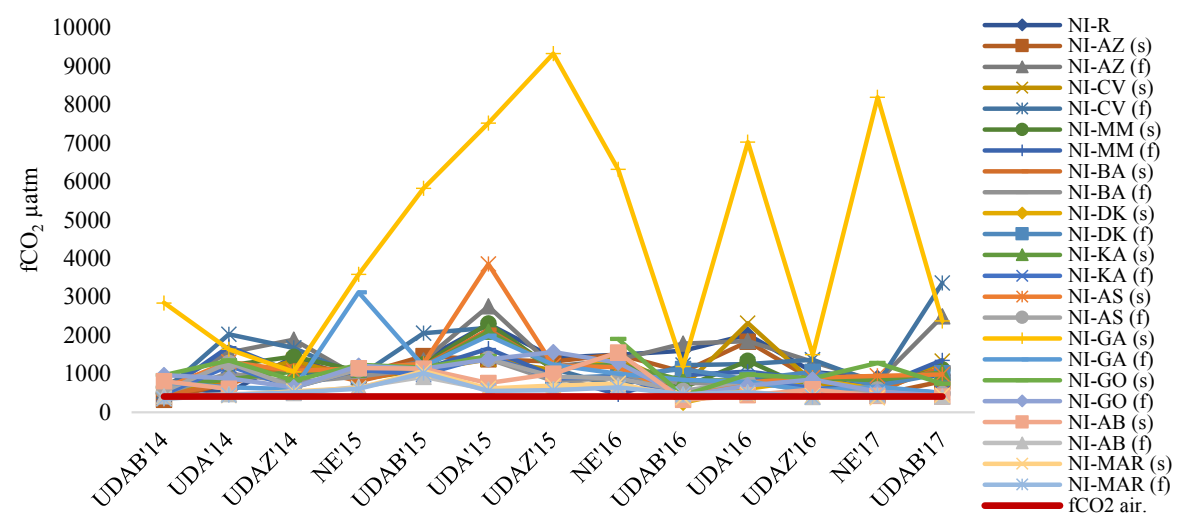

13. irudia. $\mathrm{fCO}_{2}$-aren balioak $\mathrm{NI}$ estuarioan laginketa kanpaina guztietan .

PL-ren kasuan, $\mathrm{fCO}_{2}$-aren iturri nagusia ibaia da. Zenbait laginketatan, ibai alboko puntuetan ere nahiko $\mathrm{fCO}_{2}$ altua aurkitu da, baina hori ibaiaren eraginagatik da. Azkenengo bost laginketetan, $\mathrm{fCO}_{2}$-a oro har baxuagoa dela dirudi ere. Bukatzeko, UR-n baino $\mathrm{fCO}_{2}$ altuagoak aurkitu dira.

NI-n $\mathrm{fCO}_{2}$ ikaragarri altua aurkitu zen GA gainazaleko uretan, $9.000 \mu \mathrm{atm}$-ko balioetara heltzeraino (atmosferako balioa baino 25 aldiz altuagoa). Aipatzekoa da laginketa-puntu honek oso pH-balio baxuak erakutsi zituela, $\mathrm{CO}_{2}(\mathrm{aq})$-ren formazioa laguntzen duena, eta ondorioz $\mathrm{fCO}_{2}$ handitzen da. Bibliografiaren arabera, beste ikerketa batzuetan, horrelako $\mathrm{fCO}_{2}$ balio altuak karbono organikoaren arnasketa heterotropikoari 
egotzi zaizkio [32]. GA-z gainera, estuarioaren bukaeran ere (AZ eta CV) $\mathrm{fCO}_{2}$ balio altuak aurkitu ziren, sakonera maximoan batez ere. Sakonerako balio altu horiek ere karbono organikoaren arnasketarekin erlazionatuta egon daitezke [33].

\section{ONDORIOAK}

$\mathrm{CO}_{2}$-aren sistemarekin erlazionatutako parametro guztiek korrelazio handia daukate gazitasunarekin [34]. Beraz, parametro horiek normalizatzen ez badira, emaitzak marearen momentuaren menpe egongo dira. Orain arte bibliografian aurkitu daitezkeen normalizazioak gazitasun-aldaketa txikietarako baino ez dute balio, eta ez dira erabilgarriak estuarioen kasurako. Oso garrantzitsua ikusten dugu eremu horretan ikertzen jarraitzea.

TA eta DIC-ari dagokienez, PL-n eta UR-n ekarpen nagusia ibaitik dator, horien arroa mugikorrak diren karbonato-mineralez osatuta daudelako. Beraz, estuarioetan aurkitzen diren balioak azaltzeko, inguruko geokimika kontuan izan behar da. Nerbioi-Ibaizabalen, aldiz, balio altuenak KA, AS eta GO ibaiadarretatik datoz.

pH-ari dagokionez, PL eta UR estuarioetan ibaiko laginek erakutsi dute $\mathrm{pH}$ balio altuenak berriro ere. Horrek indartzen du aurretik aipatutako teoria, hauen arroa mugikorrak diren karbonato-mineralez osatuta daudela. Izan ere, karbonato ioiak pH-a handitzen du. NI-n atentzioa eman du GA ibaiadarrak erakutsitako $\mathrm{pH}$ balio baxuak, zeina $\mathrm{pH}=7$ bezain balio baxuetara heldu baita. Hori oso arraroa da ur natural hauetan, eta aurkitu daitekeen azalpen bakarra antropogenoa da. Horrekin erlazionatuta, ibaiadar honek iheskortasun-balio altuenak erakutsi ditu, atmosferikoa baino 25 aldiz altuagoak.

Emaitza horiek guztiak kontuan izanda, esan daiteke PL eta UR estuarioak antzeko portaera daukatela $\mathrm{CO}_{2}$-aren sistemari dagokionez, eta beste edozein estuariotan aurkitu daitekeenaren antzekoa. Ibaitik datozen balio altuak arroaren geokimikari dagozkie, eta, beraz, normaltzat har daitezke.

Bestalde, oro har NI-n aurkitutako balioak normalak izan arren, GA ibaiadarrean oso balio ezohikoak aurkitu dira. Kontuan izanda ibai hori zenbait fabrikatatik pasatzen dela, badirudi $\mathrm{pH}$ balio baxu horiek isuri bati dagozkiola. Bilbo inguruko laginketa-puntuek ere balio ezohikoak erakutsi dituzte.

PL-ak ez dauka inolako ibaiadarrik, eta ikertutako parametroen bariazioa uniformea da estuarioan zehar. UR estuarioan kanal sintetiko bat sartzen da «I» laginketa puntuan, eta horrek iheskortasun altuak eta $\mathrm{pH}$ baxuak erakutsi ditu. NI estuarioa guztiz ezberdina da. Alde batetik, oso kutsadura handia izan du historikoki. Beste alde batetik, lau ibaiadar ditu, 
eta horiek izan dira anormaltasun gehien erakutsi dituzten puntuak. Horrek esan nahi dezake ibaiadar horiek direla nolabaiteko kutsadura baten iturri, eta, beraz, sakonki ikertu behar direla.

\section{ESKER ONAK}

Leire Kortazarrek Eusko Jaurlaritza eskertzen du doktoretza aurreko bekagatik eta Euskal Herriko Unibertsitatea (UPV/EHU) eskertzen du bere doktoretza ondorengo bekagatik, ESPDOC 2018 deialdian eskuratua.

\section{BIBLIOGRAFIA}

[1] LE QUÉRÉ, C. 2009. «Closing the global budget for $\mathrm{CO}_{2} »$. Glob. Change, 74, 28-31.

[2] IPCC. 2013. Climate Change 2013 - The Physical Science Basis: Working Group I Contribution to the Fifth Assessment Report of the IPCC. Cambridge University Press, Cambridge.

[3] MOSS, R.H., EDMONDS, J.A., HIBBARD, K.A., MANNING, M.R., ROSE, S.K., VUUREN, D.P. VAN, CARTER, T.R., EMORI, S., KAINUMA, M., KRAM, T., MEEHL, G. A., MITCHELL, J.F.B., NAKICENOVIC, N., RIAHI, K., SMITH, S.J., STOUFFER, R.J., THOMSON, A.M., WEYANT, J.P., WILBANKS, T.J. 2010. «The next generation of scenarios for climate change research and assessment». Nature, 463, 747-756.

[4] ZEEBE, R.E., WOLF-GLADROW, D. 2001. $\mathrm{CO}_{2}$ in Seawater: Equilibrium, Kinetics, Isotopes. Elsevier.

[5] FABRY, V.J., SEIBEL, B.A., FEELY, R.A., ORR, J.C. 2008. «Impacts of ocean acidification on marine fauna and ecosystem processes». ICES J. Mar. Sci. J. Cons., 65, 414-432.

[6] FEELY, R.A., SABINE, C.L., LEE, K., BERELSON, W., KLEYPAS, J., FABRY, V.J., MILLERO, F.J. 2004. «Impact of Anthropogenic $\mathrm{CO}_{2}$ on the $\mathrm{CaCO}_{3}$ System in the Oceans». Science, 305, 362-366.

[7] GATTUSO, J.-P., HANSSON, L. 2011. Ocean Acidification. Oxford University Press, New York.

[8] DICKSON, A.G. 2010. The carbon dioxide system in seawater: equilibrium chemistry and measurements In Guide to Best Practices for Ocean Acidification Research and Data Reporting. Publications Office of the European Union, Luxembourg.

[9] OSTLE, C., WILLIAMSON, P., ARTIOLI, Y., BAKKER, D.C., BIRCHENOUGH, S., DAVIS, C.E., DYE, S., EDWARDS, M., FINDLAY, H.S., GREENWOOD, N., HARTMAN, S., HUMPHREYS, M.P., JICKELLS, T., JOHNSON, M., LANDSCHÜTZER, P., PARKER, R., PEARCE, D., PINNEGAR, J., ROBINSON, C., SCHUSTER, U., SILBURN, B., THO- 
MAS, R., WAKELIN, S., WALSHAM, P., WATSON, A. 2016. Carbon Dioxide and Ocean Acidification Observations in UK Waters. Synthesis Report with a Focus on 2010-2015. University of East Anglia, UK.

[10] DICKSON, A.G. 1981. «An exact definition of total alkalinity and a procedure for the estimation of alkalinity and total inorganic carbon from titration data». Deep Sea Res. Part I: Oceanogr. Res. Pap., 28, 609-623.

[11] JOHANSSON, O., WEDBORG, M. 1982. «On the evaluation of potentiometric titrations of sea-water with hydrochloric-acid». Oceanol. Acta, 5, 209-218.

[12] DICKSON, A.G., SABINE, C.L., CHRISTIAN, J.R. 2007. Guide to Best Practices for Ocean $\mathrm{CO}_{2}$ Measurements. PICES Special Publication 3.

[13] KHOO, K.H., RAMETTE, R.W., CULBERSON, C.H., BATES, R.G. 1977. «Determination of hydrogen ion concentrations in seawater from 5 to $40{ }^{\circ} \mathrm{C}$ : standard potentials at salinities from 20 to $45 \%$. Anal. Chem., 49, 29-34.

[14] RAMETTE, R.W., CULBERSON, C.H., BATES, R.G. 1977. «Acid-base properties of tris(hydroxymethyl)aminomethane (Tris) buffers in sea water from 5 to $40{ }^{\circ} \mathrm{C} »$. Anal. Chem., 49, 867-870.

[15] HANSSON, I. 1973. «A new set of pH-scales and standard buffers for sea water». Deep Sea Res. Oceanogr. Abstr., 20, 479-491.

[16] DICKSON, A.G. 1984. «pH scales and proton-transfer reactions in saline media such as sea water». Geochim. Cosmochim. Acta, 48, 2299-2308.

[17] DICKSON, A.G. 1990. «Standard potential of the reaction: $\mathrm{AgCl}(\mathrm{s})+$ $12 \mathrm{H}_{2}(\mathrm{~g})=\mathrm{Ag}(\mathrm{s})+\mathrm{HCl}(\mathrm{aq})$, and and the standard acidity constant of the ion $\mathrm{HSO}_{4}^{-}$in synthetic sea water from 273.15 to $318.15 \mathrm{K»}$. J. Chem. Thermodyn., 22, 113-127.

[18] MILLERO, F.J. 1986. «The pH of estuarine waters». Limnol. Oceanogr., 31, 839-847.

[19] DICKSON, A.G., MILLERO, F.J. 1987. «A comparison of the equilibrium constants for the dissociation of carbonic acid in seawater media». Deep Sea Res. Part Oceanogr. Res. Pap., 34, 1733-1743.

[20] DICKSON, A.G., RILEY, J.P. 1979. «The estimation of acid dissociation constants in seawater media from potentionmetric titrations with strong base. I. The ionic product of water-Kw». Mar. Chem., 7, 89-99.

[21] BIANCHI, T.S. 2006. Biogeochemistry of Estuaries. Oxford University Press, Oxford, New York.

[22] FEELY, R.A., ALIN, S.R., NEWTON, J., SABINE, C.L., WARNER, M., DEVOL, A., KREMBS, C., MALOY, C. 2010. «The combined effects of ocean acidification, mixing, and respiration on $\mathrm{pH}$ and carbonate saturation in an urbanized estuary». Estuar. Coast. Shelf Sci., 88, 442-449.

[23] ORR, J.C., EPITALON, J.-M., GATTUSO, J.-P. 2015. «Comparison of ten packages that compute ocean carbonate chemistry». Biogeosciences, 12 , 1483-1510.

[24] RAPOSO, J.C., BARTOLOMÉ, L., CORTAZAR, E., ARANA, G., ZABALJAUREGUI, M., DE DIEGO, A., ZULOAGA, O., MADARIAGA, 
J.M., ETXEBARRIA, N. 2009. «Trace metals in oysters, Crassotrea sps., from UNESCO protected natural reserve of Urdaibai: space-time observations and source identification». Bull. Environ. Contam. Toxicol., 83, 223229.

[25] PUY-AZURMENDI, E., NAVARRO, A., OLIVARES, A., FERNANDES, D., MARTÍNEZ, E., LÓPEZ DE ALDA, M., PORTE, C., CAJARAVILLE, M.P., BARCELÓ, D., PIÑA, B. 2010. «Origin and distribution of polycyclic aromatic hydrocarbon pollution in sediment and fish from the biosphere reserve of Urdaibai (Bay of Biscay, Basque country, Spain)». Mar. Environ. Res., 70, 142-149.

[26] CAJARAVILLE, M.P., ORIVE, E., VILLATE, F., LAZA-MARTÍNEZ, A., URIARTE, I., GARMENDIA, L., ORTIZ-ZARRAGOITIA, M., SEOANE, S., IRIARTE, A., MARIGÓMEZ, I. 2016. «Health status of the Bilbao estuary: A review of data from a multidisciplinary approach». Estuar. Coast. Shelf Sci., 179, 124-134.

[27] ORBEA, A., MARIGÓMEZ, I., FERnÁNDEZ, C., TARAZONA, J.V., CANCIO, I., CAJARAVILLE, M.P. 1999. «Structure of Peroxisomes and Activity of the Marker Enzyme Catalase in Digestive Epithelial Cells in Relation to PAH Content of Mussels from Two Basque Estuaries (Bay of Biscay): Seasonal and Site-Specific Variations». Arch. Environ. Contam. Toxicol., 36, 158-166.

[28] GONZÁLEZ-OREJA, J.A., SAIZ-SALINAS, J.I. 1999. «Loss of Heterotrophic Biomass Structure in an Extreme Estuarine Environment. Estuar. Coast. Shelf Sci., 48, 391-399.

[29] KORTAZAR, L., MILEA, D., GÓMEZ-LASERNA, O., FERNÁNDEZ, L.A. 2019. «Accurate determination of total alkalinity in estuarine waters for acidification studies». TrAC Trends Anal. Chem., 114, 69-80.

[30] KORTAZAR, L., ALBERDI, S., TYNAN, E., FERNÁNDEZ, L.A. 2016. «An adapted flow injection analysis method of phosphate for estuarine samples avoiding matrix effects». Microchem. J., 124, 416-421.

[31] MA, J., BYRNE, R.H. 2012. «Flow injection analysis of nanomolar silicate using long pathlength absorbance spectroscopy». Talanta, 88, 484-489.

[32] FRANKIGNOULLE, M., BORGES, A.V. 2001. «Direct and indirect $\mathrm{pCO}_{2}$ measurements in a wide range of $\mathrm{pCO}_{2}$ and salinity values (the Scheldt estuary) ». Aquat. Geochem., 7, 267-273.

[33] CAI, W.-J., HU, X., HUANG, W.-J., MURRELL, M.C., LEHRTER, J.C., LOHRENZ, S.E., CHOU, W.-C., ZHAI, W., HOLLIBAUGH, J.T., WANG, Y., ZHAO, P., GUO, X., GUNDERSEN, K., DAI, M., GONG, G.-C. 2011. «Acidification of subsurface coastal waters enhanced by eutrophication». Nat. Geosci., 4, 766-770.

[34] KORTAZAR, L., SAEZ, J., ASTIGARRAGA, E., GOIENAGA, N., FERNANDEZ, L. 2013. "Chemometrics for the classification and calibration of seawater using the H+ affinity spectrum». Talanta, 116, 108-114. 